\title{
Silver Nanoparticles as Artificial Antennas for Enhanced Light-Harvesting and Charge Transfer in Dye-Sensitized Solar Cells
}

\author{
Eli Danladi ${ }^{1, ~ *, ~ P h i l i b u s ~ M u s a ~ G y u k ², ~ M u h a m m a d ~ S a n i ~ A h m a d ², ~ I s a h ~ B a b a ², ~ S u n d a y ~ H a b i l a ~ S a r k i ~}{ }^{3}$ \\ ${ }^{1}$ Department of Physics, Nigerian Defence Academy, Kaduna, Nigeria \\ ${ }^{2}$ Department of Physics, Kaduna State University, Kaduna, Nigeria \\ ${ }^{3}$ Department of Science Laboratory Technology, Nuhu Bamali Polytechnic, Zaria, Kaduna
}

Email address:

danladielibako@gmail.com (E. Danladi)

*Corresponding author

\section{To cite this article:}

Eli Danladi, Philibus Musa Gyuk, Muhammad Sani Ahmad, Isah Baba, Sunday Habila Sarki. Silver Nanoparticles as Artificial Antennas for Enhanced Light-Harvesting and Charge Transfer in Dye-Sensitized Solar Cells. International Journal of Materials Science and Applications. Vol. 5, No. 5, 2016, pp. 214-221. doi: 10.11648/j.ijmsa.20160505.16

Received: September 14, 2016; Accepted: September 22, 2016; Published: October 11, 2016

\begin{abstract}
We present an investigation on introducing core-shell $\mathrm{Ag} @ \mathrm{SiO}_{2}$ nanoparticles $(\mathrm{NPs})$ into dye-sensitized solar cells. $\mathrm{Ag} @ \mathrm{SiO}_{2}$ present the chemical stability to iodide/triiodide electrolyte, and help to localize most of dye molecules around plasmonic silver nanoparticles (AgNPs), hence increasing the optical absorption consequently the overall conversion efficiency of the device. Deployment of the silver-modified assembly as a photo anode in dye-sensitized solar cells leads to solar-toelectrical energy conversion with an overall efficiency of $0.0088 \%$ for $\mathrm{Ag}-\mathrm{TiO}_{2}$ photo anode and $0.0176 \%$ for $\mathrm{Ag} @ \mathrm{SiO}_{2}-\mathrm{TiO}_{2}$ photo anode. This represents a $100.7 \%$ improvement over the performance of otherwise identical solar cell lacking corrosionprotected silver nanoparticles. The improvement is manifested chiefly as an increase in photocurrent density due to enhanced light harvesting by the AgNPs. The results revealed that, the performance of DSSCs could be well improved through enhancing the light absorption by local surface plasmon (LSP) effect from $\mathrm{Ag} @ \mathrm{SiO}_{2} \mathrm{NPs}$ by electronically and chemically protecting the metal from recombination and corrosion. The mechanism of getting the best utilization efficiency of LSP enhanced optical field is also investigated.
\end{abstract}

Keywords: Silver Nanoparticles, DSSCs, $\mathrm{TiO}_{2}$, SILAR, Surface Plasmon, Ag@ $@ \mathrm{SiO}_{2}$, Natural Pigment

\section{Introduction}

Solar Energy is seen as a remedy to the energy crises and environmental challenges facing the world today. This technology allows the direct conversion of photons into electrical power without resulting to both greenhouse gases and other polluting agents. The solar cell technology is categorized into three generations.

A new low cost solar cell was first reported in 1991, by Grätzel which was achieved by the successful combination of nanostructured electrode and efficient dye known as DyeSensitized Solar Cell (DSSC) which falls under the third generation photovoltaic cells [1].

Natural dyes as photosensitizers for DSSCs are very attractive because they are of low cost, abundant in supply, and sustainable [2-6].

However, the efficiency of DSSC with natural pigments is still by a factor of 3-4 lower than with synthetic dyes [7]. But natural pigments are normally non-poisonous, can be disposed easily, and should be cheaper and more environmentally friendly than synthetic metal complexes which make them advantageous [7].

Several dye pigments from plant sources have been studied among the most exploited include: chlorophylls, anthocyanins and betalains [8].

As compared to the anthocyanins, which has the functional groups $(-\mathrm{OH})$, betalains have the functional group $(-\mathrm{COOH})$ which stand out to bind better to the nanoporous semiconductor surface [9-11]. The general structure of 
betalain is shown in Figure 1. [8].

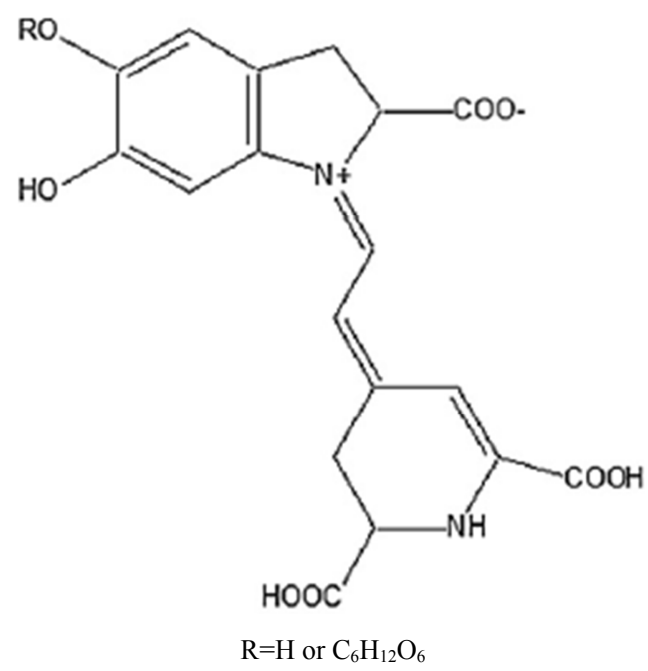

Figure 1. General structure of Betalain [8]

It is characterized by the presence of carboxylic functional group which allows short distance between the dye skeleton and the point connected to $\mathrm{TiO}_{2}$ surface, and calls for good bond formation between the $\mathrm{TiO}_{2}$ and the extract, thus enhancing the binding interaction between the pigment and the $\mathrm{TiO}_{2}$ film, which brings about good electronic coupling and electron transfer reaction in the visible spectrum $[2,4,8]$.

Introduction of metallic nanoparticles (NPs) in suitable places to trap or confine light inside the active layer and enhance the absorption in the organic semiconductor film could result to enhanced performances [12-30]. A major critical issue in plasmonic DSSCs is the stability of the NPs [31]. When introduced, metal NPs makes direct contact with the iodide/triodide-based liquid electrolyte, some problems arise, such as recombination, back reaction of the excited electrons, and corrosion of NPs. Core shell have recently been applied to address these issues [31].

In enhancing the device performance and stability of DSSC, a lot of research efforts have been demonstrated on manipulating the corresponding architecture involving inorganic and organic systems as well as various interfaces so as to enhance the cell performance [32-35].

Metal NPs embedded in sensitive places strongly interact with light at their dipole surface plasmon resonance due to the excitation of a collective electron motion inside the metal particle [36]. The surface brings about good confinement of the conduction electrons inside the particle and creates an effective restoring force leading to Surface Plasmon Resonance (SPR) effect [37]. Among the metals that demonstrates SPR modes, noble metals ( $\mathrm{Au}, \mathrm{Ag}, \mathrm{Cu}$ ) exhibit resonances in the visible or near infrared region of the electromagnetic spectrum, which is the wavelength of interest for photovoltaic applications [37].

In this research work, we report the results of a study that demonstrates a positive effect that arise from the use of silver nanoparticles as sub-wavelength antenna in DSSCs.

AgNPs successive ionic layer adsorption and reaction
(SILAR) cycle was obtained, and the uniformly coated insulated $\mathrm{SiO}_{2}$ layer effectively reduced the chemical attack of liquid iodide/triiodide electrolyte on AgNPs surface.

From our research work, it was shown that, by introducing $\mathrm{Ag} @ \mathrm{SiO}_{2} \mathrm{NPs}$, the power conversion efficiency of DSSC is enhanced $433.3 \%$ from $0.0033 \%$ to $0.0176 \%$. The related photovoltaic (PV) metrics enhancement mechanism and surface-plasmon resonances in DSSCs with Ag and $\mathrm{Ag} @ \mathrm{SiO}_{2}$ nanostructures are presented systematically.

\section{Materials and Methods}

\subsection{Materials}

Acetonitrile, Platisol, propylene carbonate, acetaldehyde, and Triton-X 100 were purchased from BDH chemicals. Silver nitrate $\left(\mathrm{AgNO}_{3}\right)$, and ethanol (99.8\%), were purchased from Sigma-Aldrich and used as received. FTO was purchased from solaronix. The surface resistance of the FTO was $15 \Omega / \mathrm{m}^{2}$, P25 $\mathrm{TiO}_{2}$ powder and $\mathrm{SiO}_{2}$ were obtained from Alfa Aesar.

\subsection{Synthesis of Nanocomposite Material for Profiling}

Dip coating method was used to synthesize the silver nanoparticles on the glass slide following the method previously demonstrated by Eli et.al [29].

\subsection{Preparation of the Natural Dye}

The natural dye was extracted with deionized water employing the following procedure: fresh flowers of Bougainvillea spectabilis were washed and air dried. $50 \mathrm{~g}$ of the sample (Bougainvillea spectabilis) was grinded to small particles using a blender with $100 \mathrm{ml}$ deionized water as extracting solvent. The solution was filtered to separate the solid residue from the pure liquid and the filtrate was used as the light harvesting pigment without further purification [6].

\subsection{Preparation of $\mathrm{TiO}_{2}$ Paste}

The $\mathrm{TiO}_{2}$ films was prepared using a modified sol-gel method, in which $2 \mathrm{~g}$ of $\mathrm{P} 25 \mathrm{TiO}_{2}$ powder was dissolved in $10 \mathrm{ml}$ of deionized water mixed with $0.2 \mathrm{~mol}$ of Triton-X 100 and $0.4 \mathrm{~g}$ of acetaldehyde, then vibrated ultrasonically for 24 hours [2].

\subsection{Preparation of Photo Anodes}

FTO conductive glass sheets, were first cleaned in a detergent solution using an ultrasonic bath for 10 minutes, rinsed with water and ethanol, and then dried [38].

$\mathrm{TiO}_{2}$ were deposited on the FTO conductive glass by screen printing technique in order to obtain a $\mathrm{TiO}_{2}$ with a thickness of $9 \mu \mathrm{m}$ and an active area of $1.80 \mathrm{~cm}^{2}$. The $\mathrm{TiO}_{2}$ film was preheated at $200^{\circ} \mathrm{C}$ for $10 \mathrm{~min}$ and then sintered at $500^{\circ} \mathrm{C}$ for $30 \mathrm{~min}$.

The second photo anode was prepared by depositing one SILAR cycle of AgNPs through successive ionic layer adsorption and reaction on the pre-deposited $\mathrm{TiO}_{2}$ film. 
The third photo anode was prepared by depositing five SILAR cycles of $\mathrm{SiO}_{2}$ on the already AgNPs modified electrode. The electrodes were immersed on the water extract of the Boungainvillea spectabilis pigment for 10-12 hours [38].

\subsection{Preparation of Counter Electrode}

The counter electrode was prepared by screen printing a platinum catalyst gel coating onto the FTO glass. It was then dried at $100^{\circ} \mathrm{C}$ and annealed at $400^{\circ} \mathrm{C}$ for $30 \mathrm{~min}$ [6].

\subsection{DSSCs Assembly}

The DSSCs photo anodes and the screen printed-Pt counter electrodes were assembled to form a solar cell by sandwiching a redox (tri-iodide/iodide) electrolyte solution. The electrolyte solution consist of $2 \mathrm{~m} \mathrm{~L}$ acetonitrile, $0.1 \mathrm{M}$ propylene carbonate, $0.005 \mathrm{M} \mathrm{LiI}, 0.0005 \mathrm{M} \mathrm{I}_{2}$. Therefore, the open side of the assembled cell were sealed properly with epoxy resin gum.

\subsection{Characterization and Measurement}

The current density-voltage $(J-V)$ characteristics of the cells were recorded using a setup made up of a xenon lamp, an AM 1.5 light filter, and a Electrochemical Analyzer (Keithley 2400 source meter) under an irradiance of $100 \mathrm{~mW} / \mathrm{cm}^{2}$. Scanning electron microscopy
(SEM) images were obtained using Phenom Pro X model, Eindhoven de Netherlands operated at an acceleration voltage of $10 \mathrm{kV}$. Visible region extinction spectra of dye, electrodes without dye and electrodes with dye were recorded on Axiom Medicals UV752 UV-vis-NIR spectrophotometer.

\section{Results and Discussion}

\subsection{Scanning Electron Microscopy (SEM)}

Fig. 2 shows the SEM images of (a) $\mathrm{TiO}_{2}$, (b) $\mathrm{TiO}_{2}-\mathrm{AgNPs}$ and (c) $\mathrm{TiO}_{2}-\mathrm{AgNPs} @ \mathrm{SiO}_{2}$ fabricated using screen printing and SILAR procedure. Fig. $2 \mathrm{a}$ is the reference electrode that shows the presence of $\mathrm{TiO}_{2}$ without AgNPs inclusion, Fig. 2b confirms the introduction of one SILAR cycle of AgNPs in the mesoporous $\mathrm{TiO}_{2}$ layer and Fig. 2c demonstrates the presence of AgNPs with one SILAR cycle protected with five SILAR cycles of $\mathrm{SiO}_{2}$ NPs. The surface morphology of the films appears not to be the same which can be attributed to the presence of AgNPs and AgNPs@ $\mathrm{SiO}_{2}$. From Fig. 2a, the image of the pure $\mathrm{TiO}_{2}$ film shows a dense surface, and there are no shining particles observed as compared to what is noticed in Fig. $2 \mathrm{~b}$ and c. the shining surface is indicative that AgNPs has the ability to scatter incident light to increase light absorption surface area.

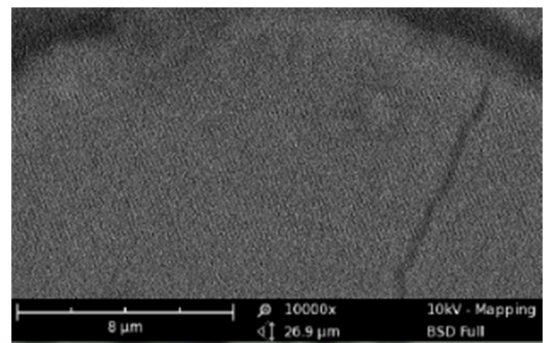

(a)

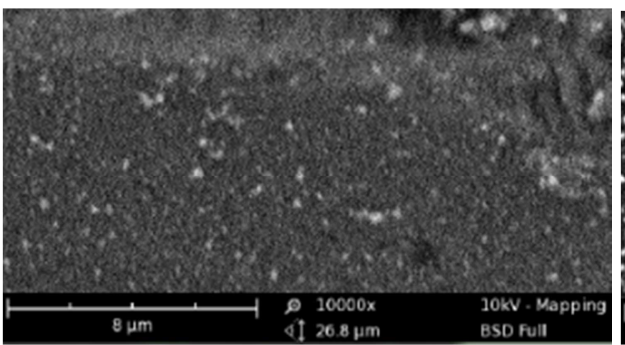

(b)

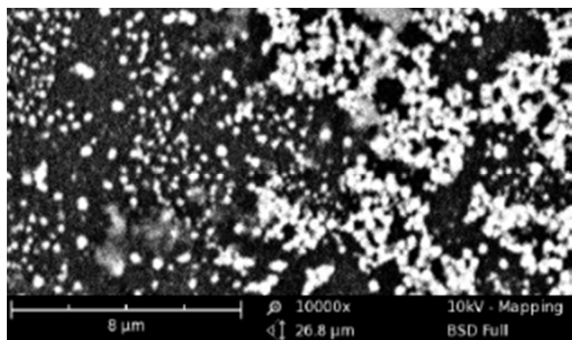

(c)

Figure 2. SEM images of (a) $\mathrm{TiO}_{2}$, (b) $\mathrm{TiO}_{2}-\mathrm{AgNPs}$ and (c) TiO $-\mathrm{AgNPS} @ \mathrm{SiO}_{2}$.

\subsection{Absorption Spectra}

Figure 3 shows the absorbance of the natural dye within the wavelength range of $400-700 \mathrm{~nm}$. The pigment is observed to have three peaks at $410 \mathrm{~nm}, 460 \mathrm{~nm}$ and 660 $\mathrm{nm}$ which ascertain the presence of betalain pigment [39]. The absorption at the visible region is indicative that this natural extract meets the requirement for its use as light harvesting pigment in this research. Fig. 4 represents the absorption spectra of the $\mathrm{TiO}_{2}$ without dye within the wavelength range of $350-1000 \mathrm{~nm}$. As depicted in the figure, $\mathrm{TiO}_{2}$ has poor absorbance in the absence of dye pigment. Fig. 5 and 6 represents various prepared AgNPs suspensions with and without corrosion protection with and without dye pigment within the wavelength range of 400-1000 nm which shows the AgNPs size around $16 \mathrm{~nm}$ which corresponds to one SILAR cycle (Fig 7). The optical absorption enhancement was observed in the dyeloaded plasmonic nanocomposite films. The relative changes in optical absorption of the AgNPs suspension films are shown in Fig. 6. This enhanced absorption and broadened spectrum absorption range of the photo anodes were mainly attributed to the SPR of AgNPs, which interacted with the dye, enhancing dye absorption that resulted in more charge carrier generation [30]. These features suggest that dye molecules in the vicinity of AgNPs can absorb more photons, presumably due to the intensified near-field effect of the surface plasmon and spectral overlap between the dye and surface plasmon, which may eventually lead to an increase in the number of charge carriers and $J_{s c}$ values [25]. 


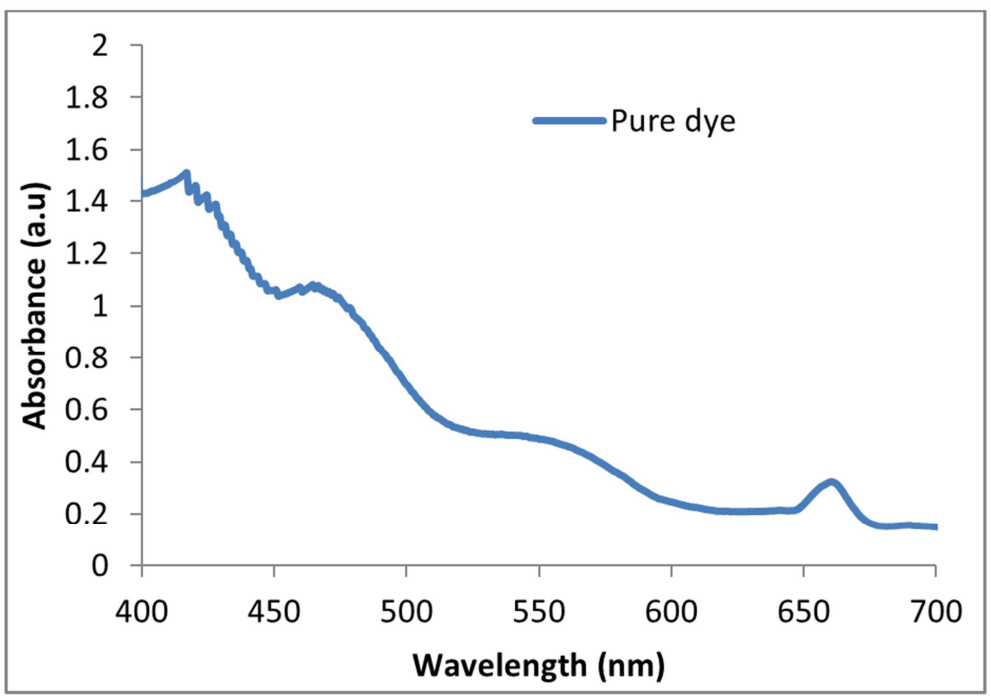

Figure 3. Absorption spectra of pure water extract dye.

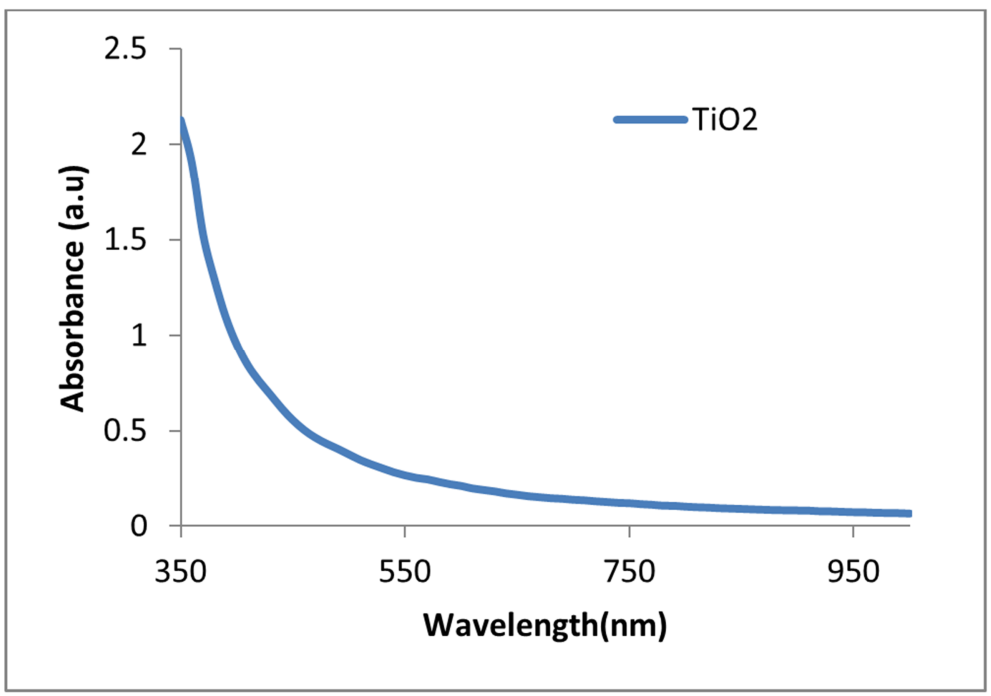

Figure 4. UV-Vis spectra of $\mathrm{TiO}_{2}$ without dye.

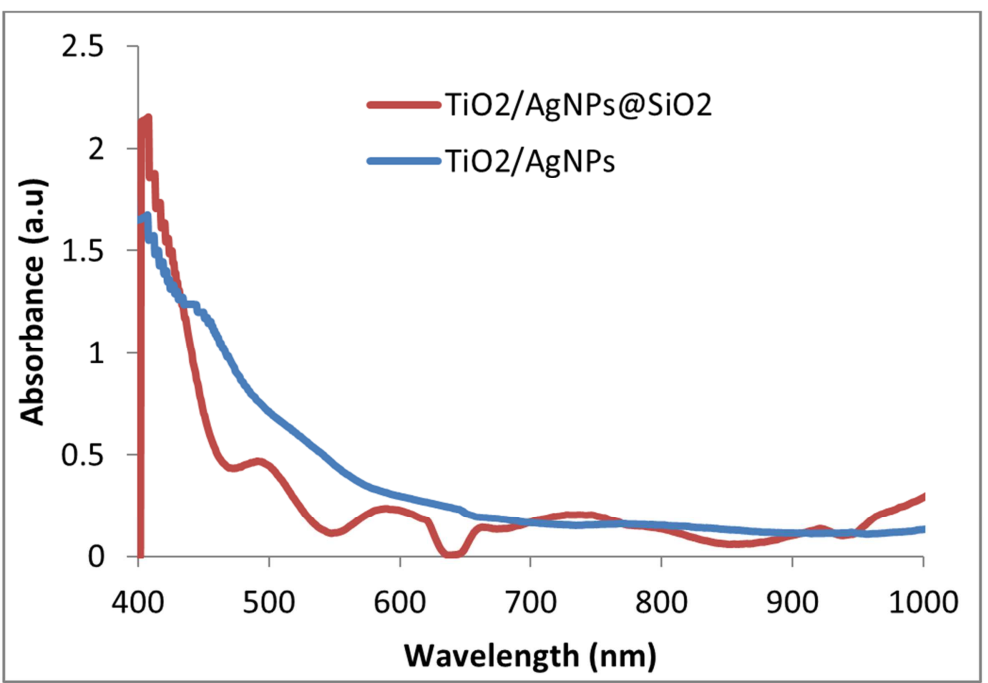

Figure 5.UV-Vis spectra of $\mathrm{TiO}_{2} / \mathrm{AgNPs}$ and $\mathrm{TiO} \mathrm{O}_{2} / \mathrm{AgNPs} @ \mathrm{SiO}_{2}$ without dye extract. 


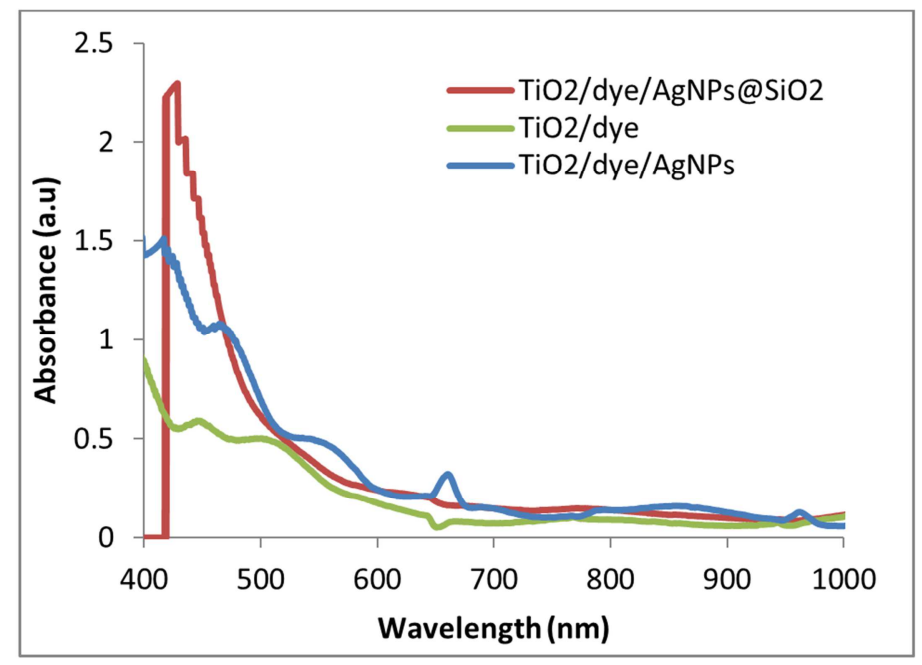

Figure 6. UV-Vis spectra of $\mathrm{TiO}_{2}, \mathrm{TiO}_{2} / \mathrm{AgNPs}$ and $\mathrm{TiO}_{2} / \mathrm{AgNPs} @ \mathrm{SiO}_{2}$ with dye extract.

\subsection{Photoelectrochemical Properties of DSSCs}

Figure 8 shows the photocurrent density-voltage characteristics $(J-V)$ curves of DSSCs with AgNPs, $\mathrm{Ag} @ \mathrm{SiO}_{2}$ $\mathrm{NPs}$ and $\mathrm{TiO}_{2}$-only. Since the three DSSCs function as junction solar cells therefore, their performance parameters can be obtained from the $J-V$ curve following equations (1) and (2) respectively [2]:

$$
\begin{gathered}
F F=\frac{J_{\text {max }} \times V_{\text {max }}}{J_{S C} \times V_{O C}} \\
\eta=\frac{F F \times J_{S C} \times V_{O C}}{P_{I R R A D I A N C E}} .100 \%
\end{gathered}
$$

where

$F F=$ Fill Factor which measures the ideality of the device, and describes how close to a square the shape of the $J-V$ curve is

$$
\begin{aligned}
& \eta=\text { solar cell efficiency } \\
& V_{\max }=\text { maximum voltage }(\mathrm{V}) ; \\
& J_{\max }=\text { maximum current density }\left(\mathrm{mA} / \mathrm{cm}^{2}\right) ; \\
& J_{S C}=\text { short circuit current density }\left(\mathrm{mA} / \mathrm{cm}^{2}\right) ; \\
& V_{O C}=\text { open circuit voltage }(\mathrm{V}) \text { and } \\
& P_{I R R A D I A N C E}=\text { light intensity }\left(\mathrm{mW} / \mathrm{cm}^{2}\right)
\end{aligned}
$$

As demonstrated in Table 1 , it is observed that the plasmon-enhanced DSSC without $\mathrm{SiO}_{2}$ protection exhibits a power conversion efficiency (PCE) up to $0.0088 \%$, which is increased by about $166.7 \%$ compared with $0.0033 \%$ of $\mathrm{TiO}_{2}$ only DSSC, while the plasmon-enhanced DSSC with $\mathrm{SiO}_{2}$ protection exhibits a PCE up to $0.0176 \%$, which is increased by about $433.3 \%$ compared with $0.0033 \%$ of $\mathrm{TiO}_{2}$-reference DSSC. In Fig. 8, the open-circuit voltage (Voc) of plasmonenhanced DSSCs and $\mathrm{TiO}_{2}$-only DSSC are almost the same, while the short-circuit current density (JSc) significantly increased by introducing $\mathrm{Ag} @ \mathrm{SiO}_{2} \mathrm{NPs}$. The improvement of $J_{S C}$ in the plasmon enhanced DSSCs was mainly caused by the increase of photocurrent due to the enhanced light absorption of dye with the help of localized surface plasmons
(LSPs) [23-25, 29-31].

Using Ag- $-\mathrm{TiO}_{2}, \mathrm{Ag} @ \mathrm{SiO}_{2}-\mathrm{TiO}_{2}$ and $\mathrm{TiO}_{2}$ nanostructured photo anodes, photocurrent-voltage performance parameters were summarized in Table 1.

Table 1. Photovoltaic performance of DSSCs with $\mathrm{TiO}_{2}, \mathrm{TiO}_{2}-\mathrm{AgNPS}_{\mathrm{N}}$ and $\mathrm{TiO}_{2}-\mathrm{Ag} @ \mathrm{SiO}_{2}$ photo anode under $100 \mathrm{mWcm}^{-2}{ }^{2}$

\begin{tabular}{lllcc}
\hline Photo anode & $\boldsymbol{J}_{\text {sc }}\left(\mathbf{m A c m}^{-\mathbf{2}}\right)$ & $\boldsymbol{V}_{\boldsymbol{~ o c ~}}(\mathbf{V})$ & $\boldsymbol{F F}$ & $\boldsymbol{\eta} \mathbf{( \% )}$ \\
\hline $\mathrm{TiO}_{2}$ & 0.015 & 0.571 & 0.400 & 0.0033 \\
$\mathrm{TiO}_{2}$-AgNPs & 0.028 & 0.542 & 0.588 & 0.0088 \\
$\mathrm{TiO}_{2}$-AgNPs@ $\mathrm{SiO}_{2}$ & 0.055 & 0.571 & 0.557 & 0.0176 \\
\hline
\end{tabular}

The reference Solar cell exhibits a short-circuit photocurrent density $\left(J_{S C}\right)$ of $0.015 \mathrm{mAcm}^{-2}$ and an opencircuit voltage $\left(V_{O C}\right)$ of $0.571 \mathrm{~V}$. On the other hand, the solar cell with AgNPs inclusion present photovoltaic performances with $J_{S C}$ and $V_{O C}$ values of $0.027 \mathrm{mAcm}^{-2}$ and $0.542 \mathrm{~V}$. The DSSC with 5 SILAR cycles of $\mathrm{SiO}_{2}$ on the $\mathrm{Ag}-\mathrm{TiO}_{2}$ photo anode gave $J_{S C}$ and $V o c$ of $0.055 \mathrm{mAcm}^{-2}$ and $0.570 \mathrm{~V}$. As it can be seen from Figure 3, the $J_{S C}$ of all DSSCs with AgNPs increased with inclusion of the plasmonic nanoparticles but more pronounced in the case were the $\mathrm{Ag} @ \mathrm{SiO}_{2}$ was coated on $\mathrm{TiO}_{2}$. From the curves, it is clear that while the opencircuit voltage of the cell with $\mathrm{TiO}_{2}$ only is similar to the cell containing $\mathrm{TiO}_{2}-\mathrm{Ag} @ \mathrm{SiO}_{2}$ photo anode, the short-circuit photocurrent density $\left(J_{S C}\right)$ with $\mathrm{TiO}_{2}-\mathrm{Ag} @ \mathrm{SiO}_{2}$ electrode $\left(0.055 \mathrm{mAcm}^{-2}\right)$ is 3.8 times higher than with $\mathrm{TiO}_{2}$ only $\left(0.015 \mathrm{mAcm}^{-2}\right)$.

The $J_{S C}$ and $\eta$ increase, demonstrates that $\mathrm{SiO}_{2}$ nanoparticles layer may protect the $\mathrm{Ag}$ nanoparticles from the chemical attack by iodide/triiodide electrolytes, which will subsequently allow regeneration by the electrolyte and decrease the recombination reaction.

As shown in Figure 8, under the same Ag deposition cycles, the cell with $\mathrm{SiO}_{2}$ capping layer presents both increased $J_{S C}$ and $V_{O C}$, indicating that $\mathrm{SiO}_{2}$ is indispensable to highly efficient dye sensitized solar cells. With the appearance of $\mathrm{SiO}_{2}$ layer, $J_{S C}$ of the cell with $\mathrm{Ag}$ SILAR cycle was improved from about $0.015 \mathrm{mAcm}^{-2}$ to 0.055 $\mathrm{mAcm}^{-2}$. The cell efficiency reached a promising $0.0176 \%$, 
indicating a 2.67 times increase over the $\mathrm{Ag}-\mathrm{TiO}_{2}$ solar cell and a 5.33 times over the bare $\mathrm{TiO}_{2}$ solar cell. In addition to the increase of the cell performance for the $\mathrm{Ag} @ \mathrm{SiO}_{2}$ configurations, a significant increase of the photochemical stability of AgNPs takes place with the presence of the $\mathrm{SiO}_{2}$ coating.

In our present work, the cell efficiency was still not high enough for practical application. The drawback limiting the energy conversion efficiency of this type of solar cells was the rather poor fill factor. This low fill factor may be ascribed to the lower hole-recovery rate of the iodide/triiodide electrolyte, leading to a higher probability for charge recombination [31].

Better results could be obtained by introducing core-shell that will present not only the chemical stability to iodide/triiodide electrolyte, but also the adhesiveness to dye molecules.

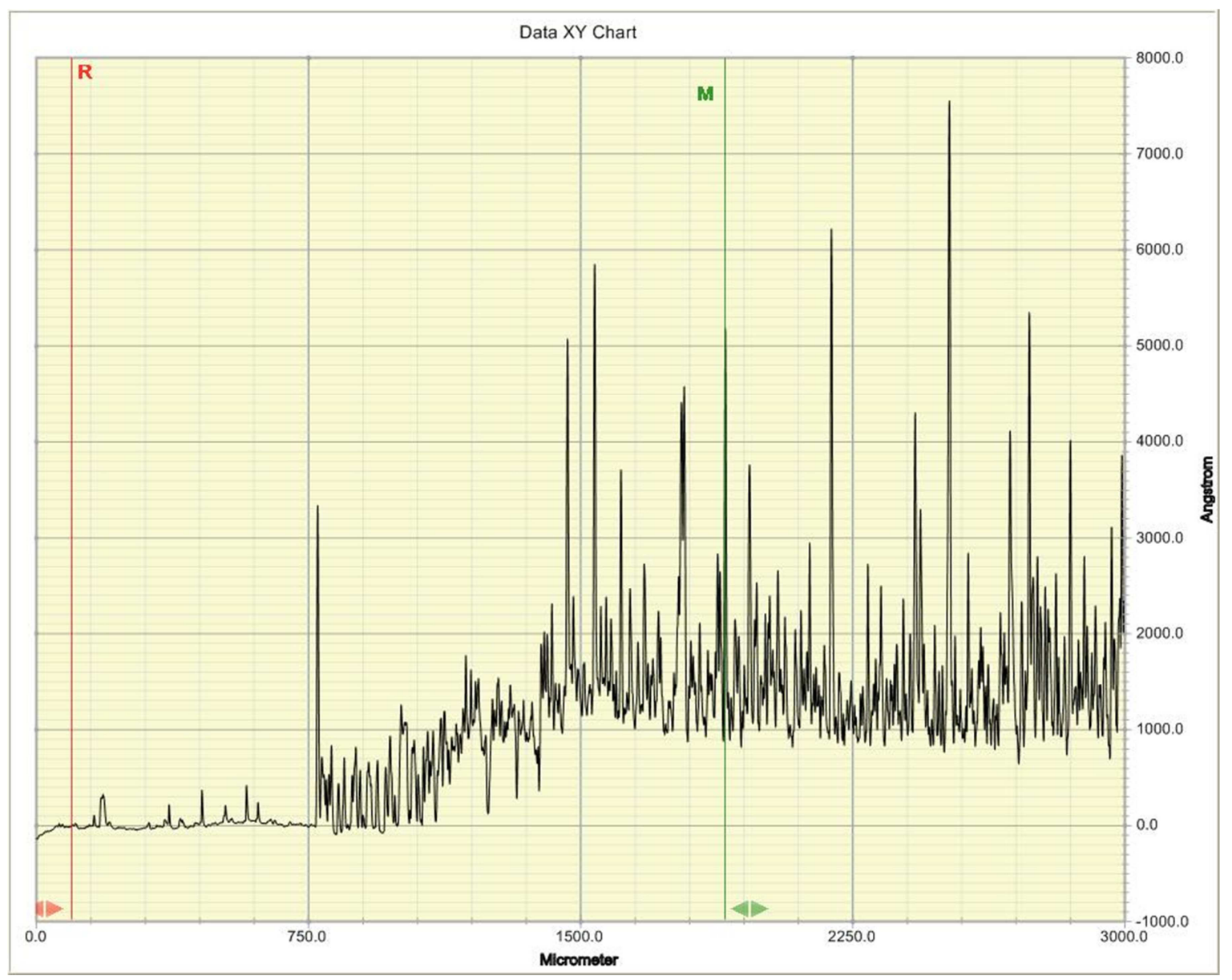

Figure 7. Surface Roughness of deposited silver nanoparticles

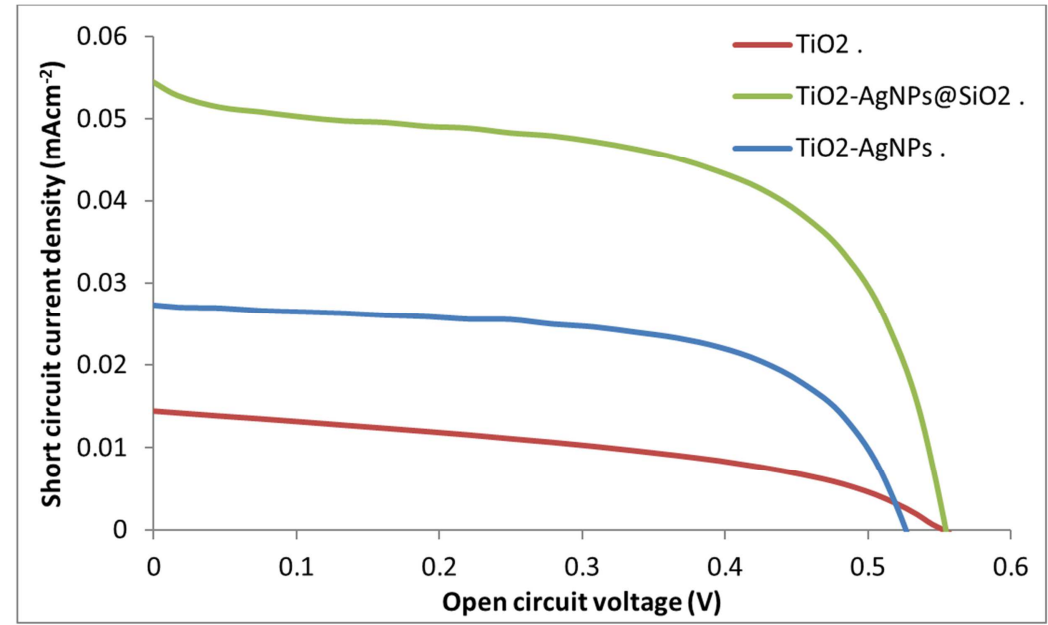

Figure 8. Photocurrent density-voltage $(J-V)$ curves of DSSCs with different photo anodes. 


\section{Conclusion}

Surface plasmon resonance effects of silver nanoparticles protected with $\mathrm{SiO}_{2}$ was demonstrated in dye sensitized solar cells. The power conversion efficiency and the current density, based on the betalain pigment were enhanced. We obtained a power conversion efficiency enhancement of $433.3 \%$ (i.e increases in $\eta$ from $\sim 0.0033 \%$ to $0.0176 \%$ ) with incorporation of $\mathrm{Ag} @ \mathrm{SiO}_{2} \mathrm{NPs}$, and a PCE improvement of $166.7 \%$ (i.e increases in $\eta$ from $\sim 0.0033 \%$ to $0.0088 \%$ ) with incorporation of AgNPs lacking protection. Part of the enhancement can be attributed to increased dye loading by the photo anodes following silver incorporation, with the remaining improvement coming from LSPR enhancement of the effective absorption cross section of the dye pigment.

\section{References}

[1] O’Regan, B., \& Gratzel, M. (1991). Low-cost A. Highefficiency solar cell based on dye-sensitized colloidal $\mathrm{TiO}_{2}$ films. Nature, 353, 737-40.

[2] Danladi E., Ezeoke J., Ahmad, M. S., Danladi E., Sarki, S. H., Iliyasu, I., \& Gyuk, P.M. (2016). Photoelectrochemical performance of dye-sensitized organic photovoltaic cells based on natural pigments and wide-bandgap nanostructured semiconductor. Physical Science International Journal, 10(2), $1-7$.

[3] Danladi, E., Onimisi, M.Y., Abdu, S.G., Ezeoke, J., \& Yakubu, S.O. (2016). Photoelectric characterization of a dyesensitized solar cell based on natural pigment extracted from Roselle (Hibiscus sabdariffa) flower and $\mathrm{TiO}_{2}$ nanoparticles. British Journal of Applied Science \& Technology, 15(2), 1-6.

[4] Danladi, E., Ahmad, M. S., Idodo, M., Danladi, E.B, Aungwa, F., \& Sarki S. H. (2016). Dye-sensitized solar cells using natural dyes extracted from Roselle (Hibiscus sabdariffa) flowers and pawpaw (Carica papaya) leaves as sensitizers. Journal of Energy and Natural Resources, 5(1), 11-15.

[5] Isah, H., Danladi E., \& Gyuk, P.M. (2015). Development of Organic Dye Sensitized Solar Cell Incorporated with $\mathrm{TiO}_{2}$ Nanostructures with Low Conversion Efficiency for Exploring Solar Energy Concepts. International Journal of Optoelectronic Engineering, 5(1), 16-19.

[6] Danladi E., Gyuk P.M., \& Danladi, E. (2016). Chlorophyll and Betalain as Light-Harvesting Pigments for Nanostructured $\mathrm{TiO}_{2}$ Based Dye-Sensitized Solar Cells. Journal of Energy and Natural Resources, 5(5), 53-58.

[7] Hug, H., Bader, M., Mair, P., \& Glatzel, T. (2014). Biophotovoltaics: Natural pigments in dye-sensitized solar cells. Applied Energy, 115, 216-225.

[8] Calogero, G., Yum, J.H., Sinopoli, A., Di Marco, G., Gratzel, M., \& Nazeeruddin. M.K. (2012). Anthocyanins and betalains as light-harvesting pigments for dye-sensitized solar cells. Solar Energy, 86, 1563-1575.

[9] Zhou, H., Wu, L., Gao, Y., \& Ma, T. (2011). Dye-sensitized solar cells using 20 natural dyes as sensitizers. Journal of Photobiology A Chemistry, 291, 188-194.
[10] Calogero, G., Di Marco, G., Cazzanti, S., Caramori, S., Argazzi, R.D.C.A., \& Bignozzi, C. (2010). Efficient dye sensitized solar cells using red turnip and purple wild Sicilian prickly pear fruits. International Journal of Molecular Sciences, 11, 254-267.

[11] Quin, C., \& Clark, A. (2007). DFT Characterization of the optical and redox properties of natural pigments relevant to dye sensitized solar cells. Chemical Physics Letters, 438, 26-30.

[12] Westphalen, M., Kreibig, U., Rostalski, J., Luth, H., \& Meissner, D. (2000). Metal cluster enhanced organic solar cells. Solar Energy Materials and Solar Cells, 61, 97-105.

[13] Rand, B.P., Peumans, P., \& Forrest, S. R. (2004). Long-range absorption enhancement in organic tandem thin-film solar cells containing silver nanoclusters. Journal of Applied Physics, 96, 7519-7526.

[14] Morfa, A.J., Rowlen, K. L., Reilly, T. H., Romero, M. J., \& van de Lagemaat, J. (2008). Plasmon- enhanced solar energy conversion in organic bulk heterojunction photovoltaics. Applied Physics Letters 92, 013504-1-013504-3.

[15] Hagglund, C., Zach, M., \& Kasemo, B. (2008) Enhanced charge carrier generation in dye sensitized solar cells by nanoparticle plasmons. Applied Physics Letters 92 (2008) 013113-1-013113-3.

[16] Wang, D.H., Kim, D.Y., Choi, K.W., Seo, J.H., Im, S.H., Park, J.H., Park, O.O., \& Heeger, A.J. (2011). Enhancement of donor-acceptor polymer bulk heterojunction solar cell power conversion efficiencies by addition of $\mathrm{Au}$ nanoparticles. Angewandte Chemie International Edition, 50, 5519-5523.

[17] Stenzel, O., Stendal, A., Voigtsberger, K., \& Vonborczyskowski, C. (1995). Enhancement of the photovoltaic conversion efficiency of copper phthalocyanine thin-film devices by incorporation of metal-clusters, Solar Energy Materials and Solar Cells, 37 (1995) 337-348.

[18] Chen, X., Zhao, C., Rothberg, L., Ng, M.K. (2008). Plasmon enhancement of bulk heterojunction organic photovoltaic devices by electrode modification. Applied Physics Letters, 93, 123302-1-123302-3.

[19] Spyropoulos, G.D., Stylianakis, M., Stratakis, E., \& Kymakis, E. (2011). Plasmonic organic photovoltaics doped with metal nanoparticles. Photonics and Nanostructures, 9, 184-189.

[20] Lagos, N., Sigalas, M. M., \& Lidorikis, E. (2011). Theory of plasmonic near-field enhanced absorption in solar cells. Applied Physics Letters, 99, 063304-1-063304-3.

[21] Min, C., Li, J., Veronis, G., Lee, L. Y. Fan, S., \& Peumans, P. (2010). Enhancement of optical absorption in thin-film organic solar cells through the excitation of plasmonic modes in metallic gratings. Applied Physics Letters, 96, 133302- 1133302-3.

[22] Zhu, J., Xue, M., Shen, H., Wu, Z., Kim, S., Ho, J.J., HassaniAfshar, A., Zeng, B., \& Wang, K.L. (2011). Plasmonic effects for light concentration in organic photovoltaic thin films induced by hexagonal periodic metallic nanospheres. Applied Physics Letters, 98, 151110-1-151110-3.

[23] Danladi, E., Onimisi, M.Y., Abdu, S.G., Gyuk, P.M., \& Ezeoke, J. (2016). Enhanced performance of a dye sensitized solar cell using silver nanoparticles modified photoanode. Journal of Scientific Research \& Reports, 10(4), 1-8. 
[24] Danladi, E., Ahmad, M. S., B. B. Ayiya, \& Babatunde, O.A. (2016). Plasmonic dye sensitized solar cells incorporated with $\mathrm{TiO}_{2}$-Ag nanostructures. International Research Journal of Pure \& Applied Chemistry, 11(3), 1-7.

[25] Onimisi, M.Y., Danladi, E., Abdu, S.G., Aboh, H.O., \& Ezeoke, J. (2016). Size effects of silver nanoparticles on the photovoltaic performance of dye sensitized solar cells. American Chemical Science Journal, 13(3), 1-8.

[26] Lin, S. J., Lee, K.C., Wu, J.L., \& Wu, J.Y. (2012). Plasmonenhanced photocurrent in dye-sensitized solar cells. Solar Energy, 86, 2600-2605.

[27] Chien, T.M., Pavaskar, P., Hung, W.H., Cronin, S., Chiu, S. H., \& Lai S. N. (2015). Study of the Plasmon energy energy transfer processes in dye sensitized solar cells; 2015.

[28] Kim, H.J.\& Kim, D.E (2012). Effect of surface roughness of top cover layer on the efficiency of dye-sensitized solar cell. Solar energy, 86 (7), 2049-2055.

[29] Danladi, E., Owolabi, J.A., Olowomofe, G.O., Onimisi, M.Y. \& Aungwa F. (2016). Enhancement in Photovoltaic Parameters of a Dye Sensitized Solar Cell by Surface Plasmon Resonance of Metallic Silver Nanoparticles. American Chemical Science Journal, 14(3), 1-8.

[30] Danladi, E., Owolabi, J. A., Olowomofe, G.O., Ezeoke J. (2016). Plasmon-Enhanced Efficiency in Dye Sensitized Solar Cells Decorated with Size-Controlled Silver Nanoparticles Based on Anthocyanins as Light Harvesting Pigment. Journal of Photonic Materials and Technology, 2(1), 2016, 6-13.

[31] Xu, Q., Liu, F., Meng, W., \& Huang, Y. (2012). Plasmonic coreshell metal-organic nanoparticles enhanced dye-sensitized solar cells, 20(S6), OPTICS EXPRESS A898.
[32] Dhas, V., Muduli, S., Agarkar, S., Rana, A., Hannoyer, B., Banerjee, R., \& Ogale, S. (2011). Enhanced DSSC performance with high surface area thin anatase $\mathrm{TiO}_{2}$ nanoleaves. Solar Energy, 85, 1213-1219.

[33] Zhang, Q., Dandeneau, C. S., Zhou, X., \& Cao, G. (2009). $\mathrm{ZnO}$ nanostructures for dye-sensitized solar cells. Advanced Materials, 21, 4087-4108.

[34] Muduli, S., Lee, W., Dhas, V., Mujawar, S., Dubey, M., Vijayamohanan, K., Han, S. H., \& Ogale, S. (2009). Enhanced conversion efficiency in dyesensitized solar cells based on hydrothermally synthesized $\mathrm{TiO}_{2}$-MWCNT nanocomposites. ACS Applied Materials \& Interfaces, 1, 2030-2035.,

[35] Hagfeldt, A., Boschloo, G., Sun, L., Kloo, L., \& Pettersson, H., (2010). Dye sensitized solar cells. Chemistry Review, 110, 6595-6663.

[36] Kreibig, U., \& Vollmer, M. (1994). Optical Properties of Metal Clusters, Springer, Berlin, 77-88.

[37] Kalfagiannis, N., Karagiannidis, P.G., Pitsalidis, C., Panagiotopoulos, N. T., Gravalidis, C., Kassavetis, S., Patsalas, P., \& Logothetidis. S. (2012). Plasmonic silver nanoparticles for improved organic solar cells. Solar Energy Materials \& Solar Cells, 104, 165-174.

[38] Zhou, H., Wu, L., Gao, Y., \& Ma, T. (2011). Dye-sensitized solar cells using 20 natural dyes as sensitizers. Journal of Photochemistry and Photobiology A: Chemistry, 219. 188194.

[39] Yazie, N., Worku, D., \& Reda. A. (2016). Natural dye as lightharvesting pigments for quasi-solid-state dye-sensitized solar cells. Materials for Renewable and Sustainable Energy, 5, 13. 